\title{
Beyni Anlamak Sadece Nörobilim ile Mümkün Mü? Beyin Yüzyılında Nörolojik Bilimlerden Sosyal Bilimlere Yeni Açılımlar, Yeni Yaklașımlar
}

\author{
Is It Possible To Understand The Brain By Only \\ Neuroscience?
}

\section{New Expansions And Approaches From Neurological Sciences To Social Sciences In The Brain Century}

\section{İ. Tayfun UZBAY (*)}

Özet

Geçtiğimiz yüzyıl boyunca beyni anlamaya yönelik çalı̧̧malar tıp alanında ve özellikle nöroanatomi, nöroloji ve beyin cerrahisi alanlarında yoğunlaşmıştı. Yüzyılın ikinci yarısından itibaren çok önemli bilimsel keşiflerle sinir hücreleri arasındaki iletişimin işleyiş biçimi ve bunun düşünce ve davranışlara katkısı ortaya konmuştur. Nörobilim çalışmaları ile beynin işleyişi ve beyin hastallklarının oluşum düzenekleri ile ilişkili önemli aşamalar gerçekleştirilmişse de alınacak daha çok yol vardır. Örneğin, zihnin ve özgür iradenin nasıl ortaya çıktığ ve nasıl işlediği hala tam olarak aydınlatılamamıştır. Öte yandan, beyin sadece tıp ile değil mühendislik gibi fen bilimlerinin başka alanlarının yanı sıra psikoloji, siyaset, hukuk, felsefe, etik ve sosyoloji gibi sosyal bilimlerin önemli alanları ile çeşitli sanat dallarının da doğrudan ilgi alanı içine girmiştir.

\footnotetext{
${ }^{(*)}$ Prof. Dr. Üsküdar Üniversitesi, Mühendislik ve Doğa Bilimleri Fakültesi, Moleküler Biyoloji ve Genetik (Türkçe) Bölüm Başkanı / Nöropsikofarmakoloji Uygulama ve Araştırma Merkezi (NPFUAM) Müdürü. tuzbay@uskudar.edu.tr
} 


\section{İ. Tayfun UZBAY}

Bunun sonucu olarak nöroetik, nöropazarlama, nörofelsefe, nörohukuk ve nörotarih gibi yeni disiplinler ortaya çıkmıştır. Bu makalede beyni daha iyi anlama sürecinde sosyal bilimlerin giderek artan katkısı güncel örnekler üzerinden irdelenmektedir.

Anahtar kelimeler: Beyin, Davranış, Zihin, Nörobilim, Sosyal bilimler

\section{Abstract}

Throughout the past century, researches to understand brain focused on medicine, specifically on neuroanatomy, neurology and brain surgery fields. After the second half of the century, the mechanism of transmission and communication between neurons and its contribution to mind and behaviors were demonstrated through several important discoveries.

Üsküdar University Journal of Social Sciences Year:1 Issue:1 Although significant improvements were made in brain functions and mechanisms of brain disorders, there is still much to be carried out. For instance, it could not be completely clarified yet how mind and free-will occur and work in brain? On the other hand, brain is not only related to medicine, but also to other areas and disciplines of life, science, social sciences, art and humanities such as engineering, psychology, politics law, philosophy, sociology and ethics. Thus, some new and interesting areas such as neuroethics, neuromarketing, neurophilosophy, neurolaw and neurohistory have developed. In this article, the ever-increasing contribution of social sciences in better understanding process of brain has been investigated with recent models.

Keywords: Brain, Behavior, Mind, Neuroscience, Social sciences

\section{Giris}

Beyin ve sinir sistemi canlı organizmaların en önemli organıdır. Bizim de dâhil olduğumuz memeliler sınıfinda diğer canlılara göre daha büyüktür. Daha büyük olması bu grup canlılarda hem anatomik hem de işlevsel yönden daha karmaşık bir yapıyı da beraberinde getirir. Tüm canlılar âleminde insan gerek yapısal gerekse işlevsel anlamda en büyük ve gizemli 
Beyni Anlamak Sadece Nörobilim ile Mümkün Mü?

beyne sahiptir. Gizemli kelimesi burada özellikle kullanılmıştır; çünkü insan beyninin çalışma prensipleri ve bazı temel işlevlerinin mekanizmaları hala net olarak aydınlatılamamıştır.

Henüz erken dönemlerini yaşamakta olduğumuz 21. yüzyıl sadece bilim çevreleri tarafından değil, devlet politikalarına yön veren siyasetçiler tarafından da beyin yüzyılı ilan edildi. Bu amaçla Amerika Birleşik Devletleri (ABD) başlangıç bütçesi sadece 2014 yılı için 100 milyon Amerikan Doları olan "Beyin İnisiyatifi Hareketi ve İnsan Beyni" projesini başlattı. Projenin tanıtımı ve ilanı 2 Nisan 2013 tarihinde bizzat Başkan Barack Obama ve Ulusal Sağlık Enstitüsü (National Institute of Health) direktörü Dr. Francis Collins tarafından gerçekleştirildi. Projenin ana hedefleri arasında yapay beyin ve yapay zekâ oluşturulması, beyinde zihin ve düşünce süreçleri ile ilişkili düzeneklerin aydınlatılması ile alzheimer, otizm ve şizofreni gibi önemli beyin hastalıklarının radikal bir biçimde tedavi edilmesi var. Beyin sadece ABD’nin ilgi alanında değil; Avrupa Birliği ülkeleri başta olmak üzere bilimsel araştırma olanağ 1 olan tüm ülkelerde araştırma teşvikleri ve ilgisi büyük ölçüde beyni anlamaya ve beyin hastalıklarını çözmeye odaklandi.

Beyin çalışmaları geçtiğimiz yüzyıl boyunca daha çok tıp odaklı yürüdü. Nöroloji, beyin ve sinir cerrahisi, biyolojik psikiyatri, psikofarmakoloji, nöroanatomi, nörofizyoloji ve deneysel nörobilim, moleküler biyoloji ve genetik ile birlikte indirgemeci yaklaşımlarla beynin anatomik olarak farklı bölgelerinin sorumlu olduğu işlevler ve bazı beyin hastalıklarının moleküler ve genetik alt yapısı hakkında önemli bilgiler sunsa da bilim insanları beynin birçok işlevi nasıl gerçekleştirdiği, örneğin zihin ve aklın nasıl oluştuğu ve nasıl kullanıldığı, bilinç kavramı, özgür irade ve beynin insan davranışlarını nasıl yönlendirdiği gibi konulara mevcut indirgemeci yaklaşımlarla yeterli bir açıklama getirmekte zorlanıyorlar. Bilinç durumlarının kendilerini oluşturduğu varsayılan nöronların faaliyetleri ile ilişkisi nedir? Bilinçli bir robot yapılabilir mi? Bilinç ile beyindeki olaylar arasındaki yakın ilişki insan özgürlüğü ve sorumluluğu konusunda ne gibi teknik sonuçlar doğurur? Bu gibi soruları çoğaltabiliriz. Beyni anlamak indirgemeci yaklaşımın aksine bütünleyici bir yaklaşımı ve farklı disiplinlerle işbirliğini gerektiriyor. $\mathrm{Bu}$ 


\section{İ. Tayfun UZBAY}

gereksinim son zamanlarda giderek artan bir şekilde nörolojik bilimlerin sosyal bilimlerin birçok alanı ile işbirliği kurmasına yol açtı. ${ }^{1}$ Bunun sonucunda önüne "nöro" eki almış sosyal bilimlerin birçok önemli alanı yeni bilim disiplinleri olarak beyni anlama odaklı çalışmalara katıldı.

$\mathrm{Bu}$ yazıda yeni gelişmelere giden süreci, yeni ortaya çıkan disiplinleri ve bunların beyni, dolayısı ile insanı anlama sürecindeki olası katkılarını tartışıp geleceğe yönelik bir öngörü oluşturmak amaçlanmıştır.

\section{Dünden Bugüne Beyin Çalıșmalarının Tarihsel Gelișimi: Nöron Keșfine Kadar Olan Dönem}

İnsanın kendi beynini anlama çabaları belki de insanlık tarihi kadar eski olmalı. İnsan ilk kez ne zaman kafatasının içinde beyin gibi bir organın bulunduğunun farkına vardı? Bunu kesin bir şekilde ortaya koyacak yazılı

Üsküdar University Journal of Social Sciences

Year:1

Issue:1 bir belgeye sahip değiliz. Muhtemelen ciddi bir yaralanma sonucu kafatas1 kırılmış ve içindeki beyin dişarı çıkmış bir vakaya ilk şahit olan kişi bunun farkına varmış ve elini kafasına götürdügüünde hissettiği sert kemik yapının aslında değerli bir organı koruduğu hissine kapılmış olabilir. Böyle bir meraka dayalı olarak beyni incelemeye yönelik ilk veriler eski çağlarda gerçekleştirilen ilkel beyin ameliyatları olarak tarif edebileceğimiz trepanasyon denilen uygulamalara ait arkeolojik bulgulara dayanmaktadır. Günümüzde yaklaşık olarak 10 bin yıl öncesine dayanan trepanasyon trepan denilen aletlerle kafatasında gerçekleştirilen operasyonlardır. ${ }^{2}$ Geçmişi tarih öncesi çağlara kadar gider. Amacı insanoğlunun muhtemelen kafanın içinde ne olup bittiğini anlamak için inceleme veya tedavi amaçlı olarak kafatasına ve beyne çeşitli aletlerle müdahale etmesi olmalı. İlgili veriler, yapılan arkeolojik kazılarda elde edilen üzerinde çeşitli delikler açılmış kafataslarına ve bu amaçla kullanıldığı aşikâr olan aletlere veya bunları tasvir eden resimlere dayanır. Trepanasyon muhtemelen ölüler kadar canlı insanlara da uygulanıyordu. Bu yolla insanlarda davranış bozukluklarına yol açan kötü ruhların açılan deliklerden çıkarak kafayı terk edeceğine ve kişinin düzeleceğine inanılıyordu. Bunun dışında trepanasyon baş ağrılarını

${ }^{1}$ Adam Zeman, Consciousness. A User's Guide, (Suffolk: Yale University Press 2002)

${ }^{2}$ Metin Özbek, "Trepanasyon. Eski çağlarda beyin ameliyatı”, Aktüel Arkeoloji, 2014, 42 (Kasım Aralık): 98-105. 
Beyni Anlamak Sadece Nörobilim ile Mümkün Mü?

gidermek, kafatası içindeki basıncı hafifletmek, travma sonrası kan ya da cerahat birikmesini önlemek ve kafatası kırıklarında kemik parçalarını temizlemek gibi amaçlarla da uygulanmış olabilir.

Diğer pek çok alanda olduğu gibi beyin ve sinir sistemi ile ilişkili ilk yazılı veriler yazının Sümerler tarafından keşfedilip kullanılmaya başladığı MÖ 4000'den sonrasına dayanır. Arkeolojik kazılarda elde edilen Mezopotamya ve Hitit dönemine ait çeşitli doğaüstü güçlerin neden olduğu davranış bozukluklarını tedavi etmeye yönelik birçok reçete içerikli kil tablet elde edilmiştir. Bunların önemli bir bölümü İstanbul'daki arkeoloji müzesinde bulunmaktadır. ${ }^{3}$ MÖ 3400'lere dayanan Sümer kil tabletlerinde de haz verici "hul gil"den söz edilmektedir. İngilizcede buna "joy plant" yani "keyif bitkisi" denilmektedir. Kast edilen bitki opiumdur (afyon). Yine aynı döneme ait alkolün tıbbi amaçlarla kullanıldığına işaret eden yazılı kanitlar da bulunmaktadır. ${ }^{4}$

Önemli yazıll belgelerden biri Misır dönemine ait Edvin Smith papirüsüdür. Papirüsün firavun veziri Rahip Imoteb tarafından yazıldığ 1 kabul edilmektedir. Bazılarına göre Mısır bilimci, bazılarına göre maceraperest Edwin Smith tarafindan Luxor'da Mustafa Aga adinda bir takasçıdan alınmıştır. Edvin Smith 1906 'da öldükten sonra papirüs kızı tarafından New-York Tarih Topluluğu'na bağışlanmıştır. Chicago Üniversitesi'nden James Breasted 1930 y1lında çevirisini tamamlanmış ve yayımlamıştır. Halen New York'ta Metropolitan Sanat Müzesi'nde sergilenmektedir. Papirüs beyin ve iç organların anatomik yapısıyla ilgili ilk bilinen tanımlamaları yapmıştır. Günümüz tedavilerine benzer olarak özellikle boyun ve spinal kord travmalarında hareketsizleştirmeye büyük önem verilmiştir. ${ }^{5}$

Beynin insan davranışları ve iletişiminin temel organı olduğunu ortaya koyan en önemli görüş MÖ 420-350 yılları arasında Batı Anadolu'da

\footnotetext{
${ }^{3}$ A.g.e.

4 "Milestones in Neuroscience Research", Erişim 1 Ağustos 2015, https://faculty.washington.edu/chudler/hist.html

${ }^{5}$ Cathy Helgason, "Commentary on the significance for modern neurology of the 17th century B.C. Surgical Papyrus”. Can J Neurol Sci, 1987, 14, 560-563.
} 


\section{İ. Tayfun UZBAY}

yaşayan tıbbın babası kabul edilen Hipokrat'tan gelmiştir. Hipokrat, "Kutsal Hastalık Hakkında" başlıklı eserinde "İnsanlar şunu bilmelidir ki tüm mutluluğumuz, sevinçlerimiz ve neşemiz gibi; kederlerimiz, acılarımız, endişelerimiz ve gözyaşlarımız da yalnızca beynimizden kaynaklanmaktadır. Bu organımız sayesinde düşünüyor, görüyor, işitiyor ve çirkinle güzeli ayırt ediyoruz. Aynı organ ile deliriyor ya da kendimizde geçiyoruz ve korkulara, paniğe kapılıyor, uykusuzluk çekiyor, uykuda yürüyoruz." ifadeleri ile beynin işlevlerini ve bozukluklarını bugünküne çok yakın bir biçimde tarif etmiştir. ${ }^{6}$ Hipokrat bu ifadeleri ile aynı zamanda Aristo zamanından beri gelen duygu ve düşüncelerin kalpte oluştuğu ile ilişkili yaygın inanışa da ciddi bir itiraz oluşturuyor, duygu ve davranışlarımızla ilişkili tek ve en yetkili organın beyin olduğuna işaret ediyordu. Aristo'nun hala süren etkisinden olsa gerek aşk ve sevginin sembolü hala kalptir. Eros sihirli okunu aşık olanların kalbine atar, Sevgililer Günü'nde çiftler birbirlerine

Üsküdar University Journal of Social Sciences Year:1 Issue:1 kırmızı kalp figürlü hediyeler alır, yürekten sevmekten ve kalbin götürdüğü yere gitmekten söz ederiz. Her ne kadar Aristo etkisi sembolik anlamda sürse de bugünkü bulunduğumuz noktada duygu, düşünce ve davranışların beyin kaynaklı olduğu konusunda Hipokrat'ın haklılığı su götürmez bir biçimde kanıtlanmıştır.

Batı Anadolu'da yaşayan ve eczacılı̆̆ın da babası olarak bilinen Bergamalı Galenos da MS 177'de yazdığı "Beyin Üzerine" isimli eserinde beynin iradeyi, bilişsel işlevleri ve belleği kontrol ettiğini ileri sürdü. Motor ve duyusal sinirleri tanımladı. Galenos'a göre beyin dokunma, tat alma, koklama, görme ve işitmenin yanı sıra aynı zamanda ruhun da merkezidir ve omurilik onun devamıdır. Beyindeki ventriküller ise "aklın" (iradenin) merkezidir. Aristo'nun aksine ruhun merkezinin kalp değil beyin olduğu görüşünü pekiştirmiştir. Galenos'un beyin üzerine görüşlerinin çoğu günümüzde de geçerliliğini korumaktadır. ${ }^{7}$

MS 900'lerin başlarında Rey kentinde yaşayan Ebubekir Razi, Kitab El-Havi isimli eserinde özellikle görme ve göz alanına özgül önemli bilimsel sonuçlar yayımlamıştır. Razi kitabında 7 önemli kranial (kafa

${ }^{6}$ Jon Queijo, Büyük Buluşlar, çev. Ekin Duru, (İstanbul: Alfa Yayınları 2011).

${ }^{7}$ Frank R. Freemon, "Galen's ideas on neurological function", J Hist Neurosci, 1994, 3: 263-271. 
Beyni Anlamak Sadece Nörobilim ile Mümkün Mü?

içi) sinir ile 31 spinal (omurilik kökenli) siniri doğru biçimde tarif etmiştir. Buharalı bilim insanı İbn-i Sina veya batı dillerindeki bilinen adı ile Avicenna 1025 yılında yazdığı El Kanun Fit Tıp isimli kitabında ruhbilim üzerine önemli saptamalarda bulunmuştur. Ruhbilim ve aklı çeşitli sınıflar altında incelemiş, görme ve göz ile ilişkili nitelikli bilgiler sunmuştur. İbn-i Sina aynı zamanda ruhsal hastalıkların müzik ile tedavi edilebileceği öngörüsünde de bulunmuştur. ${ }^{8}$ Bu bilgi 1499 yılında Edirne Darüşşifası'nda akıl hastalıklarının tedavisinde kullanılmıştır. Burada hastalar hastalıklarının niteliğine göre farklı müzik makamları veya bazı durumlarda su sesi kullanılarak tedavi edilmeye çalışılmıştır.

Bat1 dünyası Rönesans dönemi sonrası bilimde baş döndürücü bir gelişmeye sahne olmuştur. Sinir bilimleri alanında ve özellikle beyin anatomisi bağlamında bu gelişmenin en önemli ayaklarından biri Leonardo da Vinci olmuştur. Vinci önemli bir Rönesans ressamı olarak bilinir. Aynı zamanda bir nörobilimcidir ve nörobilime olan en büyük katkısı doğrudan kadavra beyinlerini gözleyerek yaptığı aslına çok yakın çizimlerdir. Leonardo da Vinci'nin kafatası ve beyin ile ilişkili çizimleri, en az diğer resimleri kadar yaratıcıdır. Vinci'nin bu çalışmaları insan vücuduna ait başka çizimleri ile birlikte tıp eğitiminde önemli bir yeri olan bugünkü anatomi atlaslarının da başlangıcı kabul edilebilir. ${ }^{9}$

"Cogito ergo sum - Düşünüyorum, öyleyse varım" sözü ile ünlü Fransız filozof ve matematikçi René Descartes "Aklın Yönetimi İçin Kurallar" isimli eserinde bugün aydınlık-karanlık döngüsüne adaptasyonda önemli olduğu anlaşılan ve kronobiyolojinin beyindeki en önemli merkezi olan pineal bez'i (epifiz) ruhun veya zihnin tahtı olarak tarif etmiştir. Bugün her ne kadar pineal bezin tek başına ruhun tahtı olmadığını biliyorsak da Descartes'ın pineal bezi tarifi ve bununla ilişkili öngörüleri 1958 yılında Aaron B. Lerner tarafından melatoninin tanımlanmasına ve kronobiyolojinin gelişimine arac1lı etmiştir. ${ }^{10}$

\footnotetext{
8 "Milestones in ..."

9 Jonathan Pevsner, "Leonardo da Vinci, neuroscientist”, Sci Am Mind, 2014, 23 (Winter): 48-55.

${ }^{10}$ Francisco López-Muñoz vd, "The historical background of the pineal gland: II. From the seat of the soul to a neuroendocrine organ", Rev Neurol, 2010, 50: 117-125.
} 


\section{İ. Tayfun UZBAY}

1600'lerin sonları ile 1900'ün başlarında nöron tarif edilip nörobilim başlayana kadar bir dizi önemli gelişme oldu. İngiliz doktor Tomas Willis 1600 'lerin sonlarına doğru ilk menenjit vakasını tanımladı, Latince beyin anatomisi kitabını yayımlad1, 11. kranial siniri tarif etti ve "nöroloji" terimini literatüre ekledi. Hollandalı bilimci Antonie Philips van Leeuwenhoek 1717'de ilk kez mikroskobu kullanarak sinir liflerinden bahsetti. 1817'de İngiliz doktor James Parkinson, kendi adı ile anılan hastalığı, 1837'de Prag Üniversitesi'nden Jan Evangelista Purkinje ise serebellar Purkinje hücrelerini tarif etti. 1847 yılında İskoç James Young Simpson ve Fransız Marie Jean Pierre Flourens ilk kez kloroformu anestezi amaçlı kullandı. 1878'de Fransız Claude Bernard, kürar ile sinir-kas iletisinin bloke olduğunu gözlemledi. Bundan iki yıl sonra Polonyalı hekim Paul Ehrlich ban-beyin bariyerini tarif etti. 1880'lerin ortalarına doğru Alman psikiyatrist Emil Krapelin nervoz ve psikozlardan söz ederken Fransız bilimci Louis

Üsküdar University Journal of Social Sciences Year:1 Issue:1 Pastör kuduz aşısını buldu. 1900'lerin ilk 5 yılında, beynin işlevsel anlamda en küçük birimi olan nöronlar keşfedilmeden hemen önce, dünya beyin araştırmaları bakımından iki önemli bilim insanını tanıdı. Avusturyalı bir nörolog olan Sigmund Freud "The interpretation of Dreams" isimli kitabında günümüzde de hala tartışılmakta olan "bilinçaltı" kavramını ortaya attı. St. Petesburg Askeri Akademisi'nden Rus bilim adamı İvan Pavlov ise denek olarak kullandığı köpeklerde "koşullanmış refleks"i tarif etti. Pavlov'un çalışmaları 1904 yılında Nobel ile ödüllendirildi. ${ }^{11}$

\section{Nöronların Keșfi ve Nöron Kavramı Üzerinden Gelișen Nörobilim}

Yirminci yüzyılın hemen başında beyni anlama yolunda gerçekleşen en önemli gelişme beynin işlevsel anlamda en önemli hücrelerinden biri olan nöronun keşfedilmesidir. Nöronun keşfi ve sonrasında işlevlerinin anlaşılmasına yönelik yeni gelişmeler bir taraftan beyin ve davranış ekseninde birçok yeni bilgiye yol açarken diğer taraftan alg1, düşünce, zihin ve davranış gibi beyin ile ilişkili her konunun doğrudan nöron faaliyetleri üzerinden açıklanmaya çalışılmasına neden oldu.

11 "Milestones in..." 
Beyni Anlamak Sadece Nörobilim ile Mümkün Mü?

Nöronların keşfine Akdeniz'de birbirine komşu sayılabilecek iki ülkenin birbirinden pek de hoşlanmayan iki bilim insanının beyin üzerinde yaptığ çalışmalar neden oldu. Nöronların ilk kez gösterilmesi onuruna İtalyan doktor ve bilim insanı Camillo Golgi erişti. Mikroskop ile beyin dokusu üzerinde yaptığ 1 çalışmalar sırasında kendi adı ile anılan ve gümüş nitrat içeren boya ile boyamayı başardığı nöronları tanımlamayı başardı. Golgi beyin dokusunun birbiriyle organik şekilde bağlı sinirlerin oluşturduğu karmaşık bir ağ - bir nevi ufak balık ağı- olduğu kanaatindeydi. Aynı dönemde beyin dokusu üzerinde mikroskobik incelemeler yapan İspanyol nöroanatomist ve histolog Santiago Ramon Y Cajal Golgi ile aynı fikirde değildi. Cajal da nöronun beynin bağımsız temel hücresi olduğunu kabul ediyor, ancak nöronların birbiri ile organik bir bağı olmadığını ve böyle bir bağ olmamasına rağmen aralarında iletişim kurabildiklerini savunuyordu. ${ }^{12}$ Cajal, 1911 yılında demansın nöron bağlantıları arasındaki iletişimin yetersizliğine neden olan bir patolojiden kaynaklanabileceğini ilk ifade eden bilim insanıdır. ${ }^{13}$ Ayrıca 1928 yılında yayımlanan kitabında "Merkezi sinir sisteminin anatomik, fizyolojik, genetik ve metabolik temel birimi tek bir nörondur ve nöronlar kendi aralarında özel bağlantılar üzerinden iletişim kurmaktadırlar." ifadesi ile sinaps tarifini de yapıyordu. ${ }^{14} \mathrm{Hem}$ Golgi hem de Cajal 1906 yılında Nobel Ödülü’nü aldılar.

Golgi ve Cajal arasındaki nöronların birbirileri ile organik bir temas halinde olup olmadıkları tartışmasında zaman Cajal'ı haklı çıkardı. Cajal'ın Nobel ödülü aldığı yıl İngiliz tıp doktoru ve nörofizyolog Charles Scott Sherrington "The integrative action of the nervous system" isimli kitabinda iki nöron arasındaki bağlantı ve iletişimin temeli olan sinapsı ve motor korteksi tarif ediyordu. Buna göre nöronlar birbirleri ile temas etmeksizin aralarında yer alan ve Angström derece ile ifade edilen sinaptik aralıkta birbirleri ile iletişim kuruyorlardı. Angström dereceyi santimetrenin 100 milyonda biri, 0.1 nanometre ya da 100 pikometre olarak ifade edebiliriz. Birbiri ile iletişim kuran iki nöron ve sinaptik aralığın birlikte oluşturduğu

\footnotetext{
12 İ. Tayfun Uzbay, "Alzheimer disease and neuroplasticity: New approaches and new targets in pharmacotherapy”, Marmara Pharmaceutical Journal, 2012, 16: 65-76.

${ }^{13}$ Santiago Ramón y Cajal, Histologie du systeme nerveux, (Paris: A. Maloine 1911).

${ }^{14}$ Santiago Ramón y Cajal, Degeneration and regeneration of the nervous sytem, (Oxford: Oxford University Press 1928).
} 


\section{İ. Tayfun UZBAY}

yapı ise sinaps adını alıyordu. Sinaps Yunanca synaptein sözcüğünden gelir. "Syn" birlikte, "haptein" kucaklamak ve "sinaptein" "birlikte kucaklamak" anlamına gelir. Sinaps nöronlar arası işlevsellik anlamında beynin en önemli oluşumudur. Beyinde yer alan yaklaşık 100 milyar nöron birbiri ile sayısız sinaps kurma alternatifine sahiptir. ${ }^{15,16}$ Sherrington bilime yaptığ 1 katkılar nedeni ile 1932 yılında Nobel Ödülü’nü aldı.

Peki, nöronlar arasındaki iletişim nasıl sağlanıyordu? Bu soruya yanıt verebilecek çalışmalar 20. yüzyılın hemen başlarında yapılmaya başlamıştı bile. Daha 1901 yılında Max H. Lewandowski ve John N. Langley adrenal bezden elde edilen bir ekstrenin sempatik sinir uyarısı ile ilişkisine dikkat çekmişti. 1905 yılında da Cambridge'de Langley'in öğrencisi olan Thomas R. Elliot bu gözlemleri daha da geliştirerek muhtelif organ ve dokularda sempatik sinir uyarımlarına bağlı olarak az miktarda adrenaline benzer

Üsküdar University Journal of Social Sciences

Year:1

Issue:1 bir maddenin salıverildiğini ve bunun efektör hücrelerle etkileştiğini ileri sürdü. Elliot'un bu meçhul maddenin nöronlar arası ileti sürecinde kimyasal bir basamağ 1 oluşturabileceği şeklindeki düşüncesi bundan sonraki çalışmalara da sşık tutan çok önemli ve yaşadığı dönemin oldukça ilerisinde bir yaklaşımd. Çok geçmeden 1907'de Cambridge'den Walter Ernest Dixon bir alkaloid olan muskarinin oluşturduğu etkiler ile vagus sinirinin uyarılması sonucu ortaya çıkan yanıtlar arasında bir benzerlik olduğunu gözledi. Bunu 1914 y1lında yine Cambridge'den İngiliz farmakolog ve fizyolog Henry Hallett Dale'in asetilkolinin etkileri ile parasempatik sinirlerin uyarılması sonucu ortaya çıkan etkilerin aynı olduğuna dikkat çekmesi ve asetilkolinin etkilerini tanımlamak için "parasempatomimetik" terimini önermesi izledi. Dale ayrıca asetilkolinin kısa etki süreli olduğunu ve bir esteraz enzimi tarafından dokularda süratle kolin ve asetik aside yıkıldığını da ileri sürmüştür. Alman farmakolog Otto Loewi de 1921 yılında vagus sinirinin uyarılmasına bağlı olarak sinir ucundan salıverilen kimyasal bir maddenin kalp atım sayısını yavaşlattığını kanıtlayarak buna "parasimpatin", adını vermişti. Daha sonra bunun nöronlar arası iletişimde

\footnotetext{
${ }^{15}$ Robert E Burke, "Sir Charles Sherrington's The integrative action of the nervous system: a centenary appreciation", Brain, 2007, 130: 887-894.

16 İ. Tayfun Uzbay, Nöropsikofarmakoloji: Rasyonel İlaç Kullanımı, (İstanbul: İstanbul Medikal Yayıncllı, 2007).
} 
Beyni Anlamak Sadece Nörobilim ile Mümkün Mü?

önemli bir nörokimyasal olan asetilkolin olduğu anlaşıldı. ${ }^{17,18,19}$ Dale ve Loewi 1936 yılında Nobel Fizyoloji ve Tıp ödülünü paylaştılar.

1930'ların başlarında kendisini aynı zamanda bir yazar ve şair olarak da tarif eden ABD'li ruhbilimci Burrhus Frederic Skinner kendi adi ile anılan Skinner Düzeneği'ni keşfetti. Bu düzenek ile deneyler yapan McGill Üniversitesi'nden James Olds 1953 yılında sıçanlarda septal bölgenin elektriksel uyarılmasının pozitif pekiştiri yaptığını ve bu bölgenin beynin ödül veya keyif merkezi olabileceğini ileri sürdü. ${ }^{20}$ İzleyen çalışmalar gerçekten de beynin bu bölgesinin özellikle de ventral tegmental alan ve nükleus akumbens isimli beyin oluşumlarının haz ve keyif merkezi olduğunu ve buradaki nöronlar arasındaki iletimden dopaminin sorumlu olduğunu ortaya koydu. Dopamin hayatımızda yer alan çikolata yemekten, cinsel ilişkiye kadar haz verici tüm olayların yanı sıra bağımlılık yapan birçok maddenin de etkilerine aracılık etmektedir. ${ }^{21}$

Aynı yıllarda Kanadalı Psikolog Donald Hebb de ileride nöroplastisite (beyin esnekliği) kavramına dönüşecek olan çalışmalarını yapmaktaydı. Hebb The Organization of Behavior isimli 1949 y1lında yayımlanan kitabında "Yeni şeyler öğrenerek beynimizi değiştirebiliriz ve bu değişiklik nöronal düzeyde oluşmaktadır." diyordu. Hebb'e göre beyin, sinaps denilen bağlantılarını çeşitli farklı varyasyonlarda oluşturarak kendini sürekli olarak yeniden modelleyebilmektedir. ${ }^{22}$ Hebbian Teori, sinaptik plastisite, nöroplastisite ya da beyin esnekliği olarak ifade edebileceğimiz kavramın temelini oluşturmuştur.

Turin Üniversitesi'nden İtalyan nörolog Rita Levi Montalcini ve Vanderbilt Üniversitesi'nden ABD’li biyokimyacı Stanley Cohen beyinde

\footnotetext{
${ }^{17}$ Henry Dale, "Pharmacology and nerve-endings (Walter Ernest Dixon Memorial Lecture): (Section of Therapeutics and Pharmacology)", Proc R Soc Med, 1935, 28: 319-332.

${ }^{18}$ Don Todman, "Henry Dale and the discovery of chemical synaptic transmission", Eur Neurol, 2008, $60,162-164$.

${ }^{19}$ Steven H Zeisel, “A brief history of choline”, Ann Nutr Metab, 2012, 61: 254-258.

${ }^{20}$ James Olds ve Peter Milner, "Positive reinforcement produced by electrical stimulation of septal area and other regions of rat brain", J Comp Physiol Psychol, 1954, 47: 419-427.

${ }^{21}$ İ. Tayfun Uzbay, Madde Bağımlılı̆̆ - Tüm Yönleriyle Bağımlılık ve Bağımlılık Yapan Maddeler, (İstanbul: İstanbul Tip Kitabevi 2015).

${ }^{22}$ Donald Hebb, The Organization of Behavior, (New York: Wiley \& and Sons 1949).
} 


\section{İ. Tayfun UZBAY}

nörotrofinler denilen, küçük miktarlarda salıverilen, nöronların hayatta kalmalarında, yaşamlarını sürdürebilmelerinde ve işlevlerini yerine getirebilmelerinde oldukça önemli bir role sahip proteinleri keşfettiler. Sinir büyüme faktörü (NGF) ve beyinden köken alan nörotrofik faktör (BDNF) bunların en çok bilinenleridir. Nörotrofinler beynin strese karşı direncinin artmasına da katkı sağlarlar. Öte yandan, ABD'de Dallas'tan Alfred Gilman ile Baltimor'dan Martin Rodbell'in iki nöron arasındaki iletişimin kilit aktörlerinden biri olan $\mathrm{G}$ proteinlerini keşfetmeleri, ardından yine ABD'li biyolog Robert Horvitz'in nöronların programlı bir şekilde ölebildiklerini ve gerektiğinde yeniden üretilebileceğini ortaya koyan çalışmaları devrim niteliğindeydi. O zamana kadar nöronların beyin gelişimi sırasında oluşup bir daha yeniden üretilemeyeceğine inanılıyordu.

İsveç’teki Göteborg Üniversitesi'nden Arvid Carlsson, ABD'de

Üsküdar University Journal of Social Sciences

Year:1

Issue:1

\section{Rockefeller Üniversitesi'nden Paul Greengard ve Columbia} Üniversitesi'nden Eric Kandel'in çalışmaları iki nöron arasındaki iletişimin detaylarını ortaya koydu. Nöronlar beyinde oluşturdukları milyarlarca sinaps üzerinden birbirleriyle iletişime geçiyorlar ve bunun sonucunda nöron zarından hücre çekirdeğine kadar ilerleyen bir yol üzerinde $G$ proteinlerinden ikincil ulaklara ve hücre DNA'sına kadar olaya katılan bir dizi aktörün ortaya çıkardığı moleküler mekanizmalar ile beynin faaliyetleri gerçekleşiyordu. Üstelik bu faaliyetler esnek ve değişken bir şekilde ortaya çıkıyordu. Esnekliği nöronların miktarı, niteliği, sinapsın hangi beyin bölgelerinde ne amaçla kurulduğu ve sürekliliği gibi faktörler belirliyordu. Nöronlar ihtiyaca göre oluşup ihtiyaca göre sinapslar oluşturabildiği gibi uzun süre kullanılmayanlar programlı bir şekilde ölebiliyordu. Bazı nöronlar ise sürekli ve sabit kalabiliyordu. Bunun en güzel örneğini beyindeki öğrenme süreçleri oluşturuyordu. Bütün bu buluşlar Hebb'in teorisini de desteklemiş ve geliştirmiştir. Başarılı çalışmaları ve yaptıkları keşiflerle Montalcini, Cohen, Gilman, Rodbell, Horvitz, Carlsson, Greengrad ve Kandel Nobel Ödülü ile onurlandırıldılar.

Beyin esnekliği beynin aslında diş iç ve dış değişiklere, özellikle strese karşı adapte olabilme yeteneğinin de temelini oluşturur. Strese ve özellikle iç veya dış değiş̧kenlere karşı direnç gösteremeyen ve adapte olamayan 
Beyni Anlamak Sadece Nörobilim ile Mümkün Mü?

beyinde depresyon başta olmak üzere birçok hastalık durumu ortaya çıkmaktadır. ${ }^{23}$

Nöronlar arasında iletişimin sinaps aralığına salıverilen çoğu amino asit yapısında olan nörokimyasallar aracılığı ile gerçekleştirildiği biliniyordu. 1950'li yılların başlarında en önemli akıl sağlığı sorunu olan şizofreninin ilaçla tedavisine yönelik çok önemli bir keşif gerçekleşti. Kimyacı Paul Charpentier'in sentezlediği klorpromazin isimli ilaç Fransız ilaç firması Rhône Poulenc (şimdiki Sanofi Aventis) tarafından geliştirildi. Farmakolog Simone Courvousier deney hayvanlarında davranış testlerinde ilacın şizofreniye iyi gelebileceğini gözlemledi ve diğer testleri tamamlayarak insanlarda da denenebileceğini ileri sürdü. İlaç ilk kez Fransa'da Paris'teki Sainte-Anne Ruh Sağlığı Hastanesinde Psikiyatristler Jean Delay ve Pierre Deniker tarafından şizofreni hastalarına uygulandı. Sonuçlar oldukça çarpıcıydı. Bu gelişme o zamana kadar kliniklerde veya toplumdan izole bir çeşit hapishane ortamında yaşamak zorunda olan şizofreni hastalarına yakınları ile birlikte yaşama ve toplum yaşamına kısmen de olsa katılma şans1 verdi. Klorpromazinin anti-dopamin karakterinde bir ilaç olmas1 şizofrenide günümüze kadar gelen dopamin teorisinin kurulmasina da aracılık etmiştir. Buna göre şizofreninin bugün pozitif semptomlar olarak tarif edilen belirtileri beynin belli bir bölgesinde dopamin aktivitesinin artışı ile ilişkilidir. ${ }^{24}$

İngiliz farmakolog John Henry Gaddum 1953 yılında bağımlılık yapan ve hayal gördüren bir madde olan LSD ile kimyasal yapısının ve bazı etkilerinin benzerliğinden yola çıkarak beyinde serotonin varlığına işaret etti. ${ }^{25} \mathrm{O}$ zamana kadar serotoninin sadece çevre dokularda damar yataklarında bulunduğu biliniyordu. İzleyen yıllarda serotoninin nöronlar arası iletişimde davranış ile ilişkili en önemli beyin nörokimyasallarından biri olduğu anlaşıldı.

\footnotetext{
${ }^{23}$ İ. Tayfun Uzbay, A New Approach to Etiopathogenezis of Depression: Neuroplasticity, (New York: NOVA Publishers, USA 2011).

${ }^{24}$ Shitij Kapur ve Yves Lecrubier, Dopamine in the Pathophysiology and Treatment of Schizophrenia, (Abington - Oxon: Taylor \& Francis 2014).

${ }^{25}$ John Henry Gaddum, "Serotonin-LSD interactions", Ann N Y Acad Sci, 1957, 66: 643-648.
} 


\section{İ. Tayfun UZBAY}

1965 y1lında Harvard Üniversitesi’nden Joseph J. Schildkraut nöronlar arası iletişimden sorumlu bir başka beyin kimyasalı noradrenalinin davranış ile ilişkisine dikkat çeken önemli bir makale yayımladı. ${ }^{26}$ Makale aynı zamanda günümüzde de geçerliliğini koruyan depresif hastalıklarla ilişkili yeni bir teoriyi ortaya koyuyordu. Schildkraut'a göre depresyona beynin bazı bölgelerinde noradrenalin aktivitesinde azalma, depresyonun tersi coşkulu ve aşırı hareketli bir ruh hali olan maniye ise aynı bölgelerde noradrenalin aktivitesinde aşırı artma neden olmaktadır. Daha sonra sadece noradrenalinin değil serotonin azlığının da depresyon ile ilişkisi ortaya kondu. Belki de bu yüzden serotonine aslında hormon olmadığı halde ve mutluluk veya haz ile hiçbir ilişkisi olmamasına rağmen "mutluluk hormonu" yakıştırması yapıldı. Bilimsel ifade olarak hatalı olsa da serotonin popüler bilim çevrelerinde ve medyada halen mutluluk hormonu olarak kabul görmektedir.

Üsküdar University Journal of Social Sciences

Year:1

Issue:1

Serotonin ve noradrenalin sadece depresyonla değil, bazı anksiyete türlerinden şizofreniye kadar çeşitli ruhsal bozuklukların nedenleri içinde de yer almaktadır. Günümüzde nöropsikiyatrik hastalıkların tedavisinde kullandığımız birçok ilaç noradrenalin ve/veya serotonin ile ilişkili sistemleri etkilemektedir. Bu çerçevede 19. yüzyıl boyunca ve 20. yüzyılın ortalarına kadar büyük ölçüde felsefe ve psikoloji ağırlıklı yürüyen psikiyatri giderek biyolojik zemine kaymaya başladı. Psikiyatri alanının önemli hastalıklarından depresyon, anksiyete ve şizofreninin oluşum nedenleri ve tedavisinde moleküler biyoloji ön plana çıktı. Biyolojik psikiyatri ayrı bir disiplin olarak epeyce taraftar buldu. Hastalıkların tedavisinde davranışçı bilişsel terapi ve psikoterapinin yerini ilaçlar daha çok almaya başladı.

Amerikalı bilim insanları Roger Guillemin ve Andrew Victor Schally sinirler arasındaki iletide sadece küçük moleküllü nörokimyasalların değil daha büyük moleküllü hormon özelliği gösteren ileticilerin de görev yaptığını kanıtladılar. Bu büyük moleküllü ileticilere nöropeptidler ya da nörohormonlar adı verildi. Bunların yeme davranışı, susama, açlık-tokluk hissi, strese direnç, haz, ağrı ve obezite gibi birçok önemli olay ile ilişkili

\footnotetext{
${ }^{26}$ Joseph J Schildkraut, "The catecholamine hypothesis of affective disorders. A review of supporting evidence", Am J Psychiatry, 1965, 122: 509-522.
} 
Beyni Anlamak Sadece Nörobilim ile Mümkün Mü?

olduğu ortaya konmuştur. Vücudumuzun kendi morfini de denilen çeşitli endorfinler, obezite ile ilişkili leptin ve grelin bunların sadece birkaçıdır. Guillemin ve Schally de beyin çalışmalarına olan bu değerli katkılarından dolayı 1977 y1lında Nobel ödülünü paylaştılar. ${ }^{27,28}$

Beyin araştırmalarında en önemli keşiflerden biri 2003 y1lında yapıldı. Japon Seiji Ogawa işlevsel manyetik rezonans görüntüleme tekniğini (functional magnetic resonance imaging, fMRI) geliştirdi. Bu üzüntü, öfke ve sevinç vb. duygusal değişiklikler esnasında veya uzun bir metni okuma gibi mental eylemleri yaparken beyni gözlemleme ve görüntüleri kaydetme olanağ 1 verdi. Giderek daha da hassas ölçümler yapabilecek şekilde gelişen bu teknik sayesinde dinamik beyni izlemek ve düşünce-eylem-beyin değişiklikleri ilişkisini kaydetmek, başka bir deyişle nöronal aktivitenin ve nöronlar arasındaki iletişimin doğrudan haritalanması mümkün oldu. ${ }^{29}$

Yakın tarihlerde İtalya'da Parma Üniversitesi'nden Giacomo Rizzolatti ayna nöron kavramını ortaya attı. Ayna nöron, bir hayvanın herhangi bir hareketi yaptığında ve aynı hareketi yapan birini gözlemlediği durumda aktive olan nöronlar için kullanılan terimdir. Primatlarda ve kuşlarda gösterilmiştir. İnsanlarda ön premotor korteks, birincil somatosensoriyel korteks ve alt paryetal kortekste lokalizedir. UCLA'dan Marco Lacoboni gibi nörologlar insan beynindeki ayna nöron sistemlerinin diğer insanların eylem ve niyetlerini anlamakta yardımcı olduğunu yani insanda empatinin nöronal temelini oluşturduğunu savunmaktadırlar. Ayna nöron sistemi ile ilgili sorunların kognitif bozukluklar ve özellikle de otizmin altında yatan nedenlerden olabileceği öne sürülmüştür. ${ }^{30,31,32}$

\footnotetext{
${ }^{27}$ Maria M Klavdieva, "The history of neuropeptides II", Front Neuroendocrinol, 1996, 17: 126-153.

${ }^{28}$ Wouter W De Herder, "Heroes in endocrinology: Nobel Prizes", Endocr Connect, 2014, 3: R94-R104.

${ }^{29}$ Seong-Gi Kim ve Seiji Ogawa, "Insights into new techniques for high resolution functional MRI", Curr Opin Neurobiol, 12: 607-615.

${ }^{30}$ Giacomo Rizzolatti ve Laila Craighero, “The mirror-neuron system”, Annu Rev Neurosci, 2004, 27 : 169-192.

${ }^{31}$ Luigi Cattaneo ve Giocamo Rizzolatti, "The mirror neuron system", Arch Neurol, 2009, 66: 557-560.

${ }^{32}$ Giocamo Rizzolatti ve Maddalena Fabbri-Destro, "Mirror neurons: from discovery to autism". Exp Brain Res, 2010, 200: 223-237.
} 


\section{İ. Tayfun UZBAY}

\section{Cevaplanamayan Sorular: Sekiz Kör Adam Bir Fili mi Tarif Ediyor?}

Beyin, zihin ve davranış konusu 21. yüzyılın başlarına kadar tamamen nöronlar arası iletişim ekseninde yürüdü. Nörobilim 21. yüzyılın yükselen değeri olurken beyinle ilişkili her şey nörona, nöronlar arası iletişime ve nöron düzeyinde beyin esnekliğine bağlanarak açıklanmaya çalışıldı. Birçok konuda başarılı da olundu. Nöronların beyin ve davranış eksenindeki önemi kesinlikle göz ardı edilemez. Bununla beraber 20. yüzyılın son çeyreğinden itibaren sadece nöronlar üzerinden deterministik yaklaşımlarla beyni anlamanın mümkün olamayacağı fikri tartışılmaya başladı. Nöronal iletişim ve nörokimya üzerinden pek çok şeyin yanıtı verilirken yanıtı alınamayan birçok yeni soru da ortaya çıkıyordu. Burada dikkat çekici problemlerden bazıları şöyle sıralanabilir:

Üsküdar University Journal of Social Sciences Year:1 Issue:1

i) Bir kere her ne kadar biyolojik psikiyatrik yaklaşımlarözellikle tedavide pratik ve hızlı bir çözüm getirir gibi görünse de ilaçla tedavi şizofreni gibi önemli nöropsikiyatrik sorunlarda radikal bir çözüm sunamadı. En etkili tedavi bile sadece hastalık belirtilerinin baskılanmasına yardımcı oldu. İlaçların ciddi yan etkileri ve birçok olguda ilaca rağmen gözlenen ataklar bilim insanlarını yeni arayışlara itti. Dünya nüfusunun yaşlanmasıyla paralel olarak giderek artan ve ciddi bir sorun haline gelen Alzheimer hastalığının, bulunduğumuz an itibarı ile bırakın tedavi edilmesini ilerlemesinin yavaşlatılması bile tartışmalı durumda. Oysaki hastalığın nöron düzeyinde yaptığ 1 hasarlar çok iyi biliniyor. Hastaların beyinlerinde "plaklar" ve "yumaklar" denilen bazı kirli tabakalar oluşuyor. Bunları tamamen temizleyecek şekilde geliştirilen ilaçlar hastalığın ilerlemesini önleyemedi. Depresyon tedavisinde de Schildkraut'un monoamin hipotezine uymayan ve ilaçla tedaviye dirençli olan olguların sayısı hiç de az değil. Hastalıkların nöronlar arası iletişime dayanan teoriler üzerinden geliştirilen ilaçlarla radikal tedavisinin yapılamaması yeni arayışlara ve yeni yaklaşımlara kapı açtı.

ii) Beyin üzerinde gerçekleştirilen detaylı incelemeler beynin sadece nöronlardan ibaret olmadığını da ortaya koymuştur. Nöronlar beynin total kitlesinin \%10'unu oluşturur. Beynin geri kalan \%90'lık bölümü gliadır ve 
Beyni Anlamak Sadece Nörobilim ile Mümkün Mü?

gliada astrositler gibi başka hücreler de bulunmaktadır. Beynin glia yapıs1 eskiden beri bilinmesine rağmen düşünce ve davranışlar üzerine etkisi ile ilişkili çalışmalar yenidir. Bunda kuşkusuz nöron ve nöronlar arası iletişim ile ilişkili çalışmaların yolunda gitmesinin de rolü olabilir. Nöronlar aras1 iletişimin gizemi çözüldükçe ve elde edilen veriler ile bazı sorulara yanıt alınamadıkça bilim insanları beynin başka hücrelerine de yöneldiler. Son zamanlarda glia hücrelerinden olan astrositlerin de en az nöronlar kadar beyin-davranış ilişkisinde rolü olduğunu kanıtlayan çalışmalar peş peşe literatürde görülmeye başladı. ${ }^{33}$ Amerikalı nörobilimci Andrew Koob Türkçe'ye de çevrilen "Düşüncenin Kökeni, The Root of Thought" isimli kitabında glianın önemine değiniyor ve nöronları glianın yönettiğini ileri sürüyor. $\mathrm{Bu}$ güne kadar önemli nöropsikiyatrik hastalıkların tedavisinde radikal bir çözüme gidilememesinin nedeninin sadece nöron odaklı çalışmalar olduğunu düşünüyor. Glial hücrelerden astrositleri iyi anlarsak bunun hastalıkları anlama ve tedavide daha etkili olacağını savunuyor. ${ }^{34}$

Koob'un görüşlerine katılmamak mümkün değil. Temkinli bir kabul ile yaklaşılsa bile beynin \%90'ını oluşturan gliayı göz ardı edemeyiz. Çalışmalar ilerledikçe konu daha da netleşecektir. Ancak Koob haklı ise ki haklılık payı var gibi görünüyor ve ayrıca beyin faaliyetlerini ve bunun davranışa yansımalarını sadece nöronlar üzerinden açıklayamıyorsak, gelecekte muhtemelen terminolojide bazı radikal değişiklikler yapmak gerekebilir. Örneğin, beynin sadece \%10'unu kapsayan hücreler üzerinde gelişen nörobilim alanı tek başına beyni anlamaya yetmeyebilir. Belki de nörobilim yerine "beyin bilimi" ifadesi daha doğru olacak. Nörobilim ancak beyin biliminin altında bir yan dal olarak faaliyetini sürdürecek. Koob kitabında bunun gerçekleşebileceğini düşündüren birçok kanıt sunuyor.

iii) Beyni anlama yolunda bugün bulunduğumuz nokta ünlü Japon kaligrafi sanatçısı Hanabusa Itcho'nun sekiz kör adamın bir fili tarif ettiği ünlü betimlemesindeki duruma çok benziyor. Kör adamların fil üzerinde dokunduğu her noktayı farklı tarif etmesi; örneğin dişini yoklayıp mızrak,

\footnotetext{
${ }^{33}$ Nicola J Allen, “Astrocyte regulation of synaptic behavior", Annu Rev Cell Dev Biol, 2014, 30: 439463.

${ }^{34}$ Andrew Koob, Düşüncenin Kökeni, çev. Nilgün Güngör, (İstanbul: Alfa Basım Yayım Dă̆ı̆ıı San. ve Tic. Ltd. Şti. 2011).
} 


\section{İ. Tayfun UZBAY}

kuyruğunu hortum ve gövdesini duvar olarak tarif etmesi gibi, sadece nöronlar arası iletişime odaklanıp indirgemeci bir yaklaşım ile beyni ele almanın asıl resmin ıskalanmasına ya da yanlış ifade edilmesine neden olduğu fikri tıp ve fen bilimleri alanında bile giderek daha çok kabul görüyor.

iv) İlginç noktalardan biri de beynimizi çözmeye çalışırken kullandığımız en önemli elemanın yine beynimiz olması. İnsanoğlu yüzyıllar boyunca beynini kullanarak birçok yeni keşifler yaptı. Yerçekimi kanunundan, evrim teorisine kadar hayata yön veren buluş ve yenilikler insanın aklını yani beynini kullanmasının ürünüdür. İnsan kendi organizmasını ve birçok organının çalışma prensiplerini de yine beynini kullanarak anladı. İş duygu, düşünce ve davranışların kaynağı olan beyni anlamaya geldiği noktada ilginç bir ikilem veya denklemle karşılaşıyoruz: Tam olarak anlamadığımız

Üsküdar University Journal of Social Sciences

Year:1

Issue:1 beynimizi kullanarak onu tam olarak anlamak ne kadar mümkün olabilir? Bunun yanıtı salt laboratuvarda beyni veya beyin hücreleri arasındaki iletişimi inceleyerek verilemez gibi duruyor.

v) Nöron odaklı beyin-davranış yaklaşımları ile ilişkili en önemli sorunlardan biri zihin ve eylem aşamasında karşımıza çıkıyor. Buradaki soru şu: Özellikle bir eylemi yapmaya karar verici süreçlerde zihinde olayın algılanması ve eylemi yapıp yapmamaya karar verme aşaması tamamen nörokimyasalların aracılık ettiği nöronlar arası iletişimin bir sonucu olarak mı gerçekleşmekte, yoksa bu kararlar beyinde önceden alınıp nöronlara düşüncenin eyleme dönüşmesi için bir komut mu gönderilmekte? "Yumurta mı tavuktan tavuk mu yumurtadan çıkar" gibi bir durum. Bu bağlamda Kaliforniya Üniversitesi Psikoloji Bölümü'nde bilinç araştırmaları ile ünlü bir bilim insanı olan Benjamin Libet' in 1983'te yaptığı deneysel çalışmanın sonuçları son derece ilginçti. Libet bir kişinin hareket etme dürtüsünün farkına vardığ 1 anın hareket gerçekleşmeden çeyrek saniye önce olduğunu buldu. Beyindeki elektriksel aktivite artışı da hareket etme isteğini duymadan önce ortaya çıkıyordu. Bir başka deyişle insanlar hareket etme ihtiyacını bilinçli bir şekilde hissetmeden önce beyin zaten kararını vermiş oluyordu. ${ }^{35} \mathrm{Bu}$ sonuç yukarıdaki sorunun önemini artırmakla kalmıyor, bu

\footnotetext{
${ }^{35}$ Benjamin Libet vd, "Time of conscious intention to act in relaion to onset of cerebral activity
} (readiness-potential): The unconscious initiation of a freely voluntary act”. Brain, 1983, 106: 623-642. 
Beyni Anlamak Sadece Nörobilim ile Mümkün Mü?

soruya yanıt ararken farklı yaklaşımlar ve stratejilere ihtiyaç olduğunu da gösteriyor.

\section{Yeni Ufuklar Yeni Alanlar}

Yukarıda beş alt başlıkta ele alınan sorular ve sorunlar beyni anlama yolunda nöroloji, anatomi, fizyoloji, beyin ve sinir cerrahisi gibi tıp alanları dışında ilave desteğe ihtiyaç olduğunu açıkça ortaya koyuyor. Burada felsefe başta olmak üzere antropoloji, psikoloji, iletişim, sosyoloji, hukuk ve hatta tarih gibi sosyal bilimlerin birçok asli alanı işe karışmaya başladı. Önceleri bu yaklaşımlar tıp ve moleküler biyoloji çevrelerinde pek de sıcak karşılanmadı. Sosyal bilimlerin beyne dâhil olması "beyin sadece tıp ve fen bilimlerine bırakılamayacak kadar önemlidir" yaklaşımı ile multidisipliner çalışmalar dönemini başlattı. Çoktandır beyin görüntüleme faaliyetleri ile beyin çalışmaları alanına teknik olarak dâhil olan mühendislik alanlarının da daha aktif katılımı ile yeni beyin yüzyılında beyin çalışmaları daha kapsamlı ve ilginç bir hal aldı. Multidisipliner çalışmalar geliştikçe önüne -nöro eki alan bir sürü yeni disiplin ve bağımsız araştırma alanları da ortaya çıkmaya başladı.

Bunların bazıları insan yaşamının önemli sorunlarına 1 şı tutmaya çalışırken bazıları doğrudan doğruya laboratuvar çalışmalarına destek vermekte. Aşağıda kısaca bazı yeni disiplinler ve bunların beyin araştırmalarına katkısı ile ilişkili bilgi verilmiştir. Beyin sadece nöronlardan ibaret değildir derken ve multidisipliner zeminde beyni anlamaya çalışırken, yeni alanların hepsinin başına -nöro eki almış olması ilginçtir. $\mathrm{Bu}$ muhtemelen günümüze kadar ulaşan beyni anlamaya yönelik indirgemeci yaklaşımın bir yansımasıdır.

\section{Nörohukuk}

Nörohukuk özgür irade tartışmalarının bir sonucu olarak gelişmiştir. Bilerek suç işleyen veya suça yatkın olan sağlıklı bir beyin var mıdır? Ya da suç işlemeye yatkınlık hastalıklı bir beyine mi bağlıdır? İşlenen suçların özgür irade ile bağlantısı nedir? Veya özgür irade nedir? 


\section{İ. Tayfun UZBAY}

Bu sorulara nörobilim çerçevesinde çok bilinen bir örnekle bir yere kadar yanıt vermek mümkündür. Sinir bilim alanında çalışanların çok iyi bildiği bir hikâye vardır. Vermont'da demir yolu işçisi olan Phineas Gage, demir bir çubuk kullanarak patlatılacak olan bir kayanın üzerinde açılan deliği kum, fitil ve barut ile doldurmaya çalışırken gerçekleşen patlamada demir çubuğun sol gözünün altından hızla girip kafasından çıkması ile yaralanır. Beynin ön alın lobunun büyük bir kısmı parçalanan Gage bilinci açık bir şekilde ayağa kalkar ve inanılmaz bir şekilde konuşmaya da başlar. Zorlu geçen bir tedaviden sonra sağlığına kavuşan gencin karakteri ve davranışları tamamen değişir. Çalışkanlığını ve fiziksel becerilerini her ne kadar koruyor olsa da kazadan önce herkesle iyi geçinen, verimli bir şekilde çalışan, yetenekli, dengeli, çevresiyle uyumlu ve zeki bir kişi olan Gage bu olaydan sonra düzensiz, kimseye saygı göstermeyen, kurallara uymayan, kaprisli, sabırsız ve şok edici cinsel istekleri olan birine dönüşür. Bu gözlem, beynin

Üsküdar University Journal of Social Sciences

Year:1

Issue:1 ön alın lobunun kendimize veya başkalarına zarar verebilecek dürtüsel davranışları kontrol etme becerimizle, diğer bir deyişle iradi süreçler ile ilişkili olduğunu açıkça ortaya koymuştur. Öte yandan, beynin korku ve öfke merkezi kabul edilen amigdalanın hasar görmesi veya bu bölgeye bask1 yapan bir tümör olması kişiyi rahatlıkla şiddete itebilir. Şizofreni gibi hastalıklarda da kişinin dışarıdan gelen uyarıları doğru yorumlama ve uygun tepkiyi verme becerisi kaybolmuştur. Hukuk bu gibi durumlarda suçun özgür irade ile işlenmediğini kabul eder. Bununla beraber, suç işleme ve şiddet eğiliminde olanların beyinlerinde her zaman bu kadar somut ve dışarıdan gözlenebilir değişiklikler olmaz. Amigdalasına basan bir tümörü olmayan veya frontal lobunda görünür bir hasar olmayan kişiler de benzer davranışları sergileyip benzer sorunlar oluşturabilir.

Baylor Tıp Fakültesi’nden David Eagleman özgür iradenin varlığını ve suç olgusundaki yerini tartışan ilginç bilim insanlarından biri. Eagleman lisans eğitimini İngiliz Dili ve Edebiyatı Bölümü’nde yapmasının ardından nörobilim alanında doktora yaptı. Dilimize de çevrilerek ülkemizde Beynin Gizli Hayatı ismi ile popüler olan Incognito'nun yazarıdır. Kitabın ilk cümlesi Pink Floyd'a atfen "Beynimin içinde biri var ama o ben değilim"dir. ${ }^{36}$ Aslında bu sözün nerdeyse aynısı "Beni bende demen bende değilem, bir

\footnotetext{
${ }^{36}$ David Eagleman, Incognito. The Secret Lives of the Brain, (New York: Pantheonbooks 2011).
} 
Beyni Anlamak Sadece Nörobilim ile Mümkün Mü?

ben var bende benden içeri” şeklinde 13. ve 14. yüzyıllarda Anadolu'da yaşamış Türk düşünürü Yunus Emre tarafindan söylemiştir. Pink Floyd'un Yunus Emre'den etkilenip etkilenmediğini bilmiyoruz. Ancak her ikisi de muhtemelen beyin-davranış düzleminde yoğun bir iç görü ile kendilerini yani beyinlerini anlamaya çalışıyorlardı.

Eagleman da kitabı boyunca insanı, yani beyni anlamaya çalışıyor. Özgür iradenin var olup olmadığını, eğer varsa nasıl ortaya çıktığını ve hangi etkenlerce belirlendiğini tartışıyor. Bunu yaparken geçmiş ve güncel felsefi yorumlardan da faydalanmayı ihmal etmiyor. Eagleman'ın beynimizin bizi kandırabileceği şeklindeki düşüncesi ise son derece ilginç. Bu aynı zamanda yukarıda sözünü ettiğimiz beyni yine kendisini kullanarak anlamaya çalışmanın zorluğunu vurgulayan bir yaklaşım.

Eagleman özgür irade kavramını tartışırken kitabında Libet'in çalışmalarına dikkat çekiyor. Libet'in özellikle bilinçli bir eylemi gerçekleştirmek üzere bilinçsiz halde karar alması şeklinde de yorumlanabilecek olan bulguları materyalist düşünceye karşı önemli bir savunma hattı oluştururken kader kavramını ve bedende yaşayan ancak fiziksel olarak varlığını görmenin mümkün olmadığı bir güç, buna ruh da diyebiliriz, beyni yönetiyor düşüncesini savunanların işe karışmasına neden oluyor. Burada özellikle pozitif bilimlerle uğraşanların hiç te haz etmeyeceği biçimde işin içine din faktörü ve doğal olarak teoloji de giriyor. Öte yandan, özellikle materyalist kesim Libet'in bulgularının mantıklı bir açıklaması olacağını, bunun beynin bilmediğimiz bir işlevi veya bölgesinden kaynaklanan bir aktivite olduğunu düşünüyor. Libet' in bulgularının tehlikeli bir yanı, özgür irade diye bir şeyin olmayacağını savunanlara da koz vermesi. Bu durumda bir kişi hangi hatayı yaparsa yapsın, hangi suçu işlerse işlesin bunu özgür iradesi ile yapması mümkün görülmüyor. Ya da hiç kimse şu an itibarı ile fiziksel olmayan bir varlık olan özgür irade ile fiziksel bir varlık olan beynin nasıl bir etkileşim içinde olduğunu veya gerçekten böyle bir etkileşim olup olmadığını tartışmasız bir biçimde ortaya koyamıyor. Eğer bu doğru ise hukuk kavramının temelden radikal bir değişikliğe ihtiyacı var gibi görünüyor. Eagleman bunu "ileriye 


\section{İ. Tayfun UZBAY}

bakan, beyinle uyumlu bir hukuk sistemi" olarak tarif ediyor. ${ }^{37}$

Nörohukukun bir başka önemli parçası da hukukun her zaman adaleti temin edememesidir. Bundaki en büyük sorunlardan biri karar verici bölgeyi işgal eden hukuk adamlarının niteliğidir. Birçok kişi karar verici konumda olan savcı ve hâkimlerin basit yanılgıları ile hiç te hak etmedikleri ağır cezalara çarptırılabiliyor. ABD'li bilişsel psikolog Elizabeth Loftus beynin hatalı anılar üretebileceği ve hâkimlerin karar verirken en büyük dayanakları olan görgü tanıklarının hatalı algıları ile onları yanıltabileceğini kanıtlayan birçok dramatik olayı bilimsel olarak kanıtlamış durumdadır. Hatalı anılar ya da algılar beynin kişiyi veya karşısındakini bir aldatma girişimi de olabilir. ${ }^{38,39}$

Öte yandan adaletin sağlanmasında vicdanın önemi de yine nörohukuk

Üsküdar University Journal of Social Sciences

Year:1

Issue:1 alanının tartışmalarından biridir. Pratikteki hukuk, adalet sistemi gelişmemiş ülkelerde çok defa sorunludur. Bir sosyal yapılanmanın hukukudur; otonom değil, heteronomdur. Tarih boyunca hep eşitsizliğin üzerine oturur. Bask1 dönemlerinde bu eşitsizlik gizlenemez olur ve hukuk ondan görece beklenen otonomiyi tamamen kaybeder; meşruiyet perdesi ardındaki güç ve şiddet tüm çıplaklığı ile öne çıkar. Sözde yüce idealler adına, insanlık, cemaat, ulus, devlet ya da Tanrı adına savunma olanakları acımasızca yok edilir. Adalet bedensel-düşünsel tekil bir varlık olan insan adına asla işlemez. ${ }^{40}$

Adaletin gerçekleşebilmesi için en önemli elemanın vicdan olduğu söylenir. Kendini başkalarının yerine koymak ve her tür eyleme objektif bakabilmek için vicdan sahibi olmak gerekir. Böylece vicdan insanı kendisine ve başkalarına karşı adil olmaya zorlar. Vicdan olmadan adalet sağlanamaz. Vicdan ön yargılardan ve içgüdülerden arınmış olmalıdır. Aksi durumda hukuksuzluğun dayanağ olur. $^{41}$ Ön yarg1 ve içgüdülerden arınmış olan vicdan "çekirdek vicdandır". Herhangi bir güce veya güç

${ }^{37}$,A.g.e., s. 1.

${ }^{38}$ Elizabeth F Loftus, "Memory distortion and false memory creation", Bull Am Acad Psychiatry Law, 1996, 24: 281-295.

${ }^{39}$ Elizabeth F Loftus, "Eyewitness testimony in the Lockerbie bombing case", Memory, 2013, 21 : 584-590.

${ }^{40}$ Cemal Bali Akal, Hukuk ya da Kukla Tiyatrosu, (Ankara: Dost Kitabevi 2014).

${ }^{41}$ Güven Güzeldere, "Vicdan bazen sılar", PsikeArt (Vicdan), 2013, 25: 6-14. 
Beyni Anlamak Sadece Nörobilim ile Mümkün Mü?

odağına biat ederek makamını ve yetkisini bu çerçevede kullanan bir hukuk adamının da vicdanı yok değildir. Burada "mazeret vicdanı" veya "sosyal vicdan" devreye girer. Bağımsız gibi görünen ama aslında bir türlü bağımsız olamayan mahkemeler en iyimser yaklaşımla bireyden ziyade devlet adına karar verirken sosyal vicdanlarından gelen kanaate göre karar verirler. Toplum yaşantısında sosyal vicdanın neden daha baskın olduğu ve bunda beynin işleyiş biçiminin katkısı sadece nörohukukun değil sosyal psikolojinin de önemli bir araştırma alanıdır. Yukarıda sözünü ettiğimiz, empati ile ilişkilendirilen ayna nöronların sağlığı ve doğru çalışması belki vicdan konusu ile ilişkili olabilir. Ayrıca yargılayıcı konumda olanların ruh sağlığının yerinde olup olmadığı, zaafları ve düşünme biçimleri de adaletin tecellisini etkileyen önemli faktörler arasındadır.

Görüldüğü gibi nörohukukun birçok çözüm bekleyen problemi var. Bunların çözümü için tek başına nörohukuk da yeterli görünmüyor. Yine multidisipliner bir işbirliği gerekiyor.

\section{Nörofelsefe}

Helenistik felsefenin en ünlü düşünürlerinden biri olan Epikuros “Ak1l hastalıklarına çare olarak felsefeden yararlanılır; öyleyse felsefe, aklın ilacıdır." derken o zaman ismi konmamış olsa da nörofelsefe alanına ait bir şeyler söylüyordu. Belki de felsefenin başına illa da beyinle ilişkili bir alanda dolaştığını vurgulamak için -nöro ön eki koymak son derece gereksizdir. Çünkü felsefe önemli ölçüde düşünceye dayanır. Düşünce ise beyinde olan biten bir süreçtir. Beyni, ya da insanı anlama sürecinde felsefe olmazsa olmaz bir disiplindir. Yüzyılımız beyin yüzyılı olup nörobilim yükselen değer olunca felsefenin önüne konulan -nöro eki belki de onu daha ilgi çekici ve kulağa hoş gelir yaptı. Bununla beraber felsefe beyni anlamak üzere çalışırken "nöro"ya yani sadece nörona takılırsa kendini daha baştan sınırlamış olur ki bu aynı zamanda felsefeyi indirgemeci çizgiye çeker. Dolayısıyla kişisel düşüncem beyni anlama konusunda atölye çalışmaları yapan felsefenin "nöro" veya "beyin” gibi ilavelerle özelleştirilmesine gerek olmadığı. İlla bir ek konulacaksa "nöro" yerine "beyin" tercih edilebilir. 


\section{İ. Tayfun UZBAY}

Felsefe açısından en önemli gelişmelerden biri psikoloji ve psikiyatri ile işbirliğine gitmesidir. Beyin yüzyılında felsefe danışmanlarının önemi giderek artmakta, konusu ve ilgi alanı ne olursa olsun odağı insan olan tüm kurum ve kuruluşlarda vazgeçilmez kadrolu elemanlar haline gelmektedirler. Avrupa'nın dört bir yanında ve Kuzey Amerika'da sayıları her gün artan felsefe kafeleri açılıyor. Fikir alışverişi günümüzün stresli dünyasında son derece değerli bir metadır ve genellikle bedavadır. Sokrates herkesi kabul eden, her şeyi herkesle her koşulda tartışan bir Agora filozofuydu. Felsefe kafeleri insanlara birbirleri ile düzeyli bir ortamda hayatın anlamı, ahlak, inanç sistemleri ve adalet gibi konularda karşılıklı fikir alışverişinde bulunabilecekleri mekânları sunuyor. Tartışma gruplarında tek temel kural nezakettir.

Davranışçı bilişsel terapiler insanların sorunlarını anlamasına yardımcı

Üsküdar University Journal of Social Sciences Year:1 Issue:1 olmasının ötesinde her zaman sorunu çözmelerine aynı ölçüde yardım etmiyor. Psikolog ve psikiyatristlerin felsefecilerle işbirliği yapması insanın kendini ve sorunu anlamasının yanı sıra çözme becerisini de önemli ölçüde artırıyor. Bu nedenle Amerika ve Avrupa Birliği ülkelerinde bu tür işbirliği yapabilen felsefe kuruluşları, sayıları giderek artan psikoterapi için felsefi danışmanlara çatı sağlıyor. Felsefe, psikoloji ve psikiyatri işbirliği insanlara sorunlarını kalıcı bir şekilde çözme becerisi kazandırmasının yanında daha erdemli ve daha kendi ile barışık, neşeli bir birey olma özelliği kazandirıyor. $^{42}$

Fransız felsefeci Catherine Malabou da "her insan kendi beynini inşa edebilir" derken muhtemelen "her insan kendi beyninin heykeltıraşı olabilir" diyen ve beyin esnekliği (nöroplastisite) kavramının babası kabul edebileceğimiz Santiago Ramon Y Cajal'a atıfta bulunuyor. Malabou günümüz nörofelsefecilerinin en tanınmışlarından biridir. Beyin esnekliği ile felsefeyi birleştiren ve beyni esnek bir zeminde felsefenin yardımı ile anlama çabası içinde olan araştırma ve yazıları ile tanınıyor. "What Should We Do with Our Brain?" ve New Mexico'dan başka bir felsefeci Adrian Johnston ile birlikte yazdığı "Self and Emotional Life" isimli kitapları

\footnotetext{
${ }^{42}$ Lou Marinoff, Prozac'ı Bırak Platon'a Bak. Felsefe Terapisi, (İstanbul: Profil Yayınc1lık 1999).
} 
Beyni Anlamak Sadece Nörobilim ile Mümkün Mü?

bu çalışmalarına örnek gösterilebilir. ${ }^{43,44}$ İkinci kitapta Johston ile birlikte felsefe, psikoanaliz ve nörobilim çerçevesinde insan duygularını ve hayata yansımalarını irdeliyorlar.

Daha önce sorduğumuz en çetin sorunlardan olan beyin işleyişini kendi beynini kullanarak anlamaya çalışma sürecini sağ $l_{1 k} l_{1}$ bir şekilde aşabilmek için galiba en çok multidisipliner çalışmaya hevesli felsefecilerin yardımına ihtiyacımız var.

\section{Nöropazarlama}

Nöropazarlama doksanlı yılların ikinci yarısında, ilk kez Harvard Üniversitesi'nden Prof. Gerry Zaltman'in işlevsel manyetik rezonans tomografi (fMRI) cihazını pazarlama araştırmalarında kullanması ile başlamıştır. fMRI belli bazı hareketler ya da duygulanımlar sırasında beyinde hangi bölgelerin aktivite gösterdiğini saptamak için gerçekleştirilen bir beyin görüntüleme yöntemidir. Bu çalışmaların amacı, kişilerin ticari değeri olan bir nesneyi almaya karar verirken beynin hangi bölgelerinin aktive olduğunu saptamaktı. ${ }^{45}$

Nöropazarlama 2000'li yılların başlarından itibaren pazarlamanın ana hedefi olan insanda beynin nasıl çalıştığını ve nasıl karar verdiğini bilimsel yöntemlerle ölçen yeni bir bilim alanı olarak oldukça gelişti. Kullanılan teknikler de giderek genişledi. Günümüzde sadece fMRI değil, Pozitron Emisyon Tomografi (PET), Elektro Ensefalo Grafi (EEG), Gözbebeği Genişletme Tekniği (PDR) ve Magneto Ensefalo Grafi (MEG) gibi önemli sinir sistemi hastalıklarının tanısında ve tedavinin takibinde kullanılan oldukça sofistike yöntem ve cihazlar nöropazarlama amaçl1 olarak da kullanılmaktadır. Hollywood'da gişe başarısı yüksek filmlerin çekiminde, önemli markaların ürün reklamlarında ve hatta yeni otomobillerin dizaynında nöropazarlama tekniklerinden etkin bir biçimde yararlanılmıştır. ${ }^{46}$

\footnotetext{
${ }^{43}$ Catherine Malabou, What Should We Do Our Brain? (New York: Fordham University Press 2008).

${ }^{44}$ Catherine Malabou, Self and Emotional Life, (New York: Columbia University Press 2013).

${ }^{45}$ Tayfun Uzbay, "Nöropazarlama ve beyin ödül sistemi”, Pi Pazarlama ve İletişim Kültürü Dergisi Nöropazarlama: Tüketici nasıl karar alır? 2014, 13(47) Kıș: 46-50.

${ }^{46}$ İzzet Bozkurt, Pazarlama İletişimde Sihirli Dokunuşlar, (İstanbul: Kapital Medya Hizmetleri 2013).
} 


\section{İ. Tayfun UZBAY}

Tüketicilerin beynini ve duygularını analiz ederek hangi markayı, rengi, kokuyu, müziği ve yiyeceği neden tercih ettiğini veya etmediğini isabetli bir şekilde saptamak küreselleşen dünyada yeni ürünlerin tüketime sunulması veya mevcut olanların tüketiminin sağlanması bakımından son derece önemlidir. Bu nedenle pazarlayacak iddialı ürünleri olan önemli markaların bu alana ilgisi giderek artmaktadır. Nöropazarlama araştırma-geliştirme faaliyetlerinin de bir parçası olarak nörobilim içinde hızla gelişmiş ve günümüzde bir alt disiplin haline gelmiştir. Öyle ki, ülkemizde de bazı seçkin üniversiteler iletişim fakülteleri içinde lisansüstü nöropazarlama programları açmaktadır.

Üsküdar University Journal of Social Sciences Year:1

Issue:1

Nöropazarlama tekniklerinde hedef, piyasada alıcıların alışveriş̧ sırasındaki eğilimlerini belirlemek ve buna uygun satış stratejileri geliştirmek gibi görünse de uygulamada bazı etik sorunlar oluşturması olasıdır. Bunun en büyük nedeni insanların alış veriş yapma isteklerinin bağımlılık yapan birçok madde gibi beyin ödül sistemi ile doğrudan ilişkili olması ve alış verişin takıntılı bir saplantıya dönüşerek bağımlılığa yol açabilmesidir.

Küreselleşmeye paralel olarak insanların ürünleri satın almalarını sağlama ve satış1 yapılacak ürünün sürümünü artırmak için nöropazarlama teknikleri giderek daha çok kullanılmaktadır. Bir insanın herhangi bir malı veya hizmeti almasında onun keyif verici özelliği veya alıcının bunun keyif verici veya kendisini iyi hissettirici bir eylem olduğuna ikna edilmesi oldukça belirleyicidir. $\mathrm{Bu}$ noktada beyin ödül sistemi ve nöronlar arası iletiden sorumlu dopamin anahtar role sahiptir. Ödül sistemine hitap eden ve cazibesi ile onu uyaran her şey doğru bir şekilde sunulduğunda mutlaka talep yaratacaktır. Öte yandan iradi düzeneğin önemli bölgesi olan beyin ön alın lobu çocuklarda ve ergenlerde henüz tam olarak gelişmediği için bu yaş grubunun erişkinlere göre çok daha risk alıcı ve dürtüsel davrandığını iyi biliyoruz. Bu noktada enerji içecekleri gibi gençler tarafından daha kolay tüketilebilecek ürünlerin doğrudan gençler hedef alınarak onlara zarar verecek şekilde pazarlanması, gençlerin hiç ihtiyacı olmayan bazı ürünler için genç odaklı pazar oluşturmak üzere çeşitli pazarlama tekniklerinin kullanılması ülkemiz gibi analitik düşünmeyi sevmeyen toplumlarda 
Beyni Anlamak Sadece Nörobilim ile Mümkün Mü?

ciddi sosyal sorunlara neden olabilecek gibi görünmektedir. Öte yandan, ödül sisteminin bağımlılık ile olan yakın ilişkisi bu sistem üzerinden gerçekleştirilecek nöropazarlama tekniklerinin doğru kurallara dayanması ve etik zemine oturtulması zorunluluğunu da beraberinde getirmektedir. ${ }^{47}$

Nöropazarlamanın gerçekten bir bilim disiplini olarak ele alınıp alınamayacağında belirleyici faktör yine önüne bir "nöro" eklenerek beyin ve davranışa özgül çalışacağ düşünülen etiktir. Etik kurallar ve kavramlar zedelenmediği sürece insanların alış veriş davranışlarının analizinde bir sakınca yoktur. Aksi durumda nöropazarlamanın sadece etik değil yasal yaptırımlarla da karşılaşması olasıdır. Belki de nöropazarlamanın kırmızı çizgilerini belirlemekte nörohukukun da yardımı olacaktır.

\section{Nörotarih}

Araştırmalarını Ortaçağ Avrupa tarihi, doğal tarih, hukuk tarihi ve antropolojisi üzerine yoğunlaştıran Harvard'dan Daniel Lord Smail nörotarih alanının gelişmesi için çaba sarf eden öncülerdendir. Smail yakın zamanlardaki çalışmalarını evrim ve paleolitik tarihteki yakın döneme odaklamış, çok eski geçmiş ile yakın geçmişi buluşturmaya çalışmış, tarihin akışı içindeki sinir bilimlerini gün ışığına çıkarmıştır. Çalışmalarında kültürel yapıların beyin-beden sistemini nasıl şekillendirdiğini ve vücudun iç dinamiklerini nasıl değiştirdiğini tartışır. Bu bakış açısı kültürel dönüşümleri anlamamız ve yorumlamamız için yeni boyutlar sağlamıştır. Smail'in çalışmaları tarihi evrimsel psikoloji ve nörobilim ile buluşturmuştur. Tarihçiler, tarihin bütün tarih-öncesi dallarını bir kenara bırakarak sadece yazılı kısmıyla ilgilenirler. Smail, tarihçilerin tarih-öncesi olarak adlandırdığı şeyin zekâ üzerindeki gelişimini ihmal etmenin kahve, tütün ve uyuşturucular gibi uyarıcıların sosyal tarihini anlamamızı fakirleştirdiğini savunur. Smail haklıysa, o zaman tarihçilerin evrim düşüncesi masasına koyacakları bir şeyleri olabilir. ${ }^{48,49}$ Smail'i ve nörotarihi anlama konusunda

\footnotetext{
${ }^{47}$ Tayfun Uzbay, A.g.e., (2014).

${ }^{48}$ Daniel Lord Smail, On Deep History and the Brain, (Berkeley: University of California Press 2007).

${ }^{49}$ Gül Eren ve Emrah Özbay, "Karl Marks ve Charles Darwin: Emeğin evrimsel tarihine doğru” (çeviri) Sosyal, Evrimsel ve Kültürel Psikoloji Dergisi, Kuzeydoğu Evrimsel Psikoloji Toplumunun 2. Yıllık Toplantı Müzakeresi, 2008, 261-290.
} 


\section{İ. Tayfun UZBAY}

başvurulacak en güzel kaynaklardan biri Smail tarafından yazılmış olan "On Deep History and The Brain" isimli kitaptır. ${ }^{50}$

\section{Nöroetik}

Etik insanlar arasındaki ilişkilerin temelinde yer alan değerleri, ahlaki bakımdan iyi ya da kötü; doğru ya da yanlış olanın niteliğini ve temellerini araştıran felsefe dalı olarak tanımlanmaktadır. Yunanca ethos (töre, gelenek, alışkanlık) sözcüğünden türetilmiştir. Belirli ahlak değerlerinden ya da ilkelerinden oluşan sistemler veya kuramlar için de bu terim kullanılır. Birbiri ile çok yakından ilişkili olan "etik" ve "ahlak" kavramları arasındaki temel ayrım, etik teriminin, genel olarak ahlakı konu alan disiplini belirtmesidir. $\mathrm{Bu}$ anlamda etik, ahlak felsefesi ile eşanlamlı kabul edilir. ${ }^{51}$

Bilimsel çalışmalar, bilimin genel kurallarına uymanın yanı sıra

Üsküdar University Journal of Social Sciences Year:1 Issue:1

problemlerin çözümüne yönelirken mutlak doğru sonucu elde etme ve uygulamaya koymada "etik" olmak zorundadır. Bu çerçevede, bilim alanında bilim etiği veya bilim ahlakı kuralları söz konusudur. Etik temellere dayanmayan bir bilimsel çalışma bilimin kurallarına tam olarak uysa bile elde edilen sonuç geçersiz olacaktır.

Etik kurallar yaşamın her alanı için geçerlidir. Bilimsel disiplinler söz konusu olduğunda ilgili alanın yanıt bulmaya çalıştığı soru veya sorunlarla ilişkili olarak etik te özelleşmiştir. Genel etik kurallar her zaman geçerli olmakla birlikte sisteme temsil ettiği disiplinden gelen bazı ilave kuralların eklenmesi kaçınılmazdır. Örneğin biyoetik genel anlamda etik disiplininin biyolojik bilimlere adapte olmuş halidir diyebiliriz. Biyoetik canlı kavramı ve yaşama hakkı çerçevesinde uyulması gereken kuralların yanı sıra biyolojik bilimler alanında yapılacak bilimsel çalışmaların kırmızıçizgilerini de belirler. ${ }^{52}$ İnsan sağlığı ve hastalıkların tedavisi söz konusu olduğunda da tıp etiği devreye girer. Tıp etiği biyoetik çerçevesinde de değerlendirilebilir. Tıp etiğini de içinde tutarsak, biyoetik insanların tedavi hakkı ve tedavi

\footnotetext{
${ }^{50}$ Daniel Lord Smail, A.g.e.

51 Tayfun Uzbay, "Bilimsel araştırma etiği", Orhan Yılmaz (ed.), Sağlık Bilimlerinde Süreli Yayıncılık-2006 içinde, (Ankara: TÜBİTAK Matbaası 2006), 19-26.

${ }^{52}$ Iain F Purchase, "Ethical issues for bioscientists in the new millennium", Toxicol Lett, 127: 307-313.
} 
biçiminden, doğum kontrol yöntemlerine, ötenaziden (çaresiz bir hastalığa yakalanmış kişinin kendi yaşamına son verilmesini isteme hakkı), deney hayvanları veya insanlar üzerinde gerçekleştirilecek bilimsel çalışmalara kadar birçok önemli alanı kapsamaktadır. ${ }^{53,54}$

Nöroetik biyoetik ile nörobilimin bir kesişme alanı olarak tarif edilebilir. Genel anlamıyla akıl-zihin ve davranış ile ilişkili etik konuları inceler ve tartışır. Geniş anlamda nöroetik, nörobilim araştırmalarının kendi bakış açısı ile ve nörobilimin etik, yasal ve sosyal gereklilikleri ile ilgilenir. ${ }^{55}$ Nöroetik terimi çocuk yetiştirme, teknolojik ilerlemeler ile etik düşünce ve davranışın nörolojik temeli ile ilişkili etik konulara da göndermeler yapar. $^{56,57,58}$

Günümüzde nöroetik özbenlik ve sorumluluk ilişkisinden, toplumun beyin sağlı̆̆ını ilgilendiren konularda gerek bilinçlendirilmesini içeren eğitimlerin birebir sunulması gerekse bilimsel gelişmelerin kendi beyin sağlığına yansıması gibi konularda bilgilendirilmesini içeren sosyal politikalara kadar geniş alanı kapsar. Özbenlik ve sorumluluk gibi konularda nöroetiğin yolu özgür irade, suç ve ceza gibi tartışmalar çerçevesinde nörohukuk ile kesişir. Beyin görüntüleme yolu ile yalan saptanması, bilişsel yetenekleri ve hafizayı ilaçla veya ilaçsız artırma yolları, beyni etkilediği iddia edilen bir takım ürünlerin internet yoluyla satışı ve dağıtımı, çocukların akademik başarısı için ilaç kullanımı, çocuklarda nöropsikiyatrik ilaçların kullanımı, nöropsikiyatrik ilaçların sağlık profesyonellerine veya halka tanıtım biçimi, beyin ve gen haritalama, yapay zekâ, beyin ile ilişkili

\footnotetext{
53 "General Assembly of the World Medical Association. World Medical Association Declaration of Helsinki: Ethical principles for medical research involving human subjects", J Am Coll Dent Summer, 2014, 81: 14-18.

${ }^{54}$ Henriëtte J Bout vd, "Evaluating the ethical acceptability of animal research", Lab Anim (NY), 2014, 43: 411-414.

${ }^{55}$ Judy Illes ve Stephanie J. Bird, "Neuroethics: A modern context for ethics in neuroscience", Trends Neurosci, 2006, 29: 511-517.

${ }^{56}$ Anneliese A Pontius, "Neuroethics vs neurophysiologically and neuropsycholocically uninformed influences in child-rearing and education emerging hunter-gatherers, and artificial intelligence models of the brain". Physiol Rep, 1993, 72: 451-458.

${ }^{57}$ Adina Roskies, "Neuroethics for the new millennium", Neuron, 2002, 35: 21-23.

${ }^{58}$ Martha J Farah ve Paul Root Wolpe, "Neuroethics toward broader discussion", Hastings Cent Rep, 2004, 34: 35-45.
} 


\section{İ. Tayfun UZBAY}

herhangi bir teknoloji geliştirme ve bunun transferi güncel nöroetiğin diğer popüler konuları arasındadır. ${ }^{59}$

Çocuklarda nöropsikiyatrik ilaçların kullanımının giderek artması nöroetiğin işe karıştı̆̆ 1 önemli tartışma noktalarından birini oluşturur. Bir kısım nöropsikiyatrist çocukluk döneminde karşılaşılan sorunlara ilaçla müdahale etme taraftarıdır. Böyle bir müdahalenin gelecekte çocukları daha radikal mental sorunlardan da koruyacağına inanmaktadırlar. Buna karşı çıkanların ve çocuklarda nöropsikiyatri ilaçları kullanımında daha dikkatli olunmasını savunanların da bazı haklı nedenleri vardır. Çocukta nöropsikiyatrik ilaçların kolay kullanımına sıcak bakmayanların dikkat çektiği konular arasında ilaçların geliştirilirken sadece erişkinlerde test edilmesi, nöropsikiyatrik ilaç geliştirmeye yönelik hayvan modellerinin yetersizliği, çocukluk ve ergenlikte oldukça dinamik bir şekilde gelişimini

Üsküdar University Journal of Social Sciences

Year:1

Issue:1 sürdüren beyne dışarıdan kimyasal müdahalenin sonuçlarının henüz öngörülememesi, psikiyatrik hastalıklara tanı koymada objektif verilerden çok sübjektif ölçek ve skalalardan yararlanılması, ilaç endüstrisinin yeni endikasyonlarla ürününe daha geniş alanlar açma gayreti ve nörobilimin yükseliş döneminde bazı nörobilimcilerin ilaç endüstrisi ile çıkar ilişkisi içinde olması bulunmaktadır. ${ }^{60}$

Endişeleri haklı çıkaracak bazı durumlar da söz konusu. Sporda performans artırmak için ilaç kullanılması doping olarak etiketlenip grip ilaçlarının içindeki uyarıcıya bile izin verilmezken, çocukların akademik performansını artırmak için uyarıcılardan yararlanmak ne kadar doğru? Akademik başarının nöron odaklı bir nedenle ilişkisini mevcut tanı yöntemleri ile ne kadar doğruluk içinde saptayabiliyoruz? Akademik başarının artırılması için yüksek kafeinli içeceklerin bile serbestçe çocuklara ve gençlere sunulması söz konusu. Öte yandan kafein sürekli ve giderek artan şekilde kullanıldığında bağımlılık yapıyor.

Diğer önemli tartışma alanlarından biri de yapay zekâ meselesi. Gerçekten yapay bir beyin yapılıp yapılamayacağı bir tarafa buna neden

\footnotetext{
${ }^{59}$ Judy Illes ve Stephanie J. Bird, A.g.m.

${ }^{60}$ İ. Tayfun Uzbay, “Çocuk psikiyatrisinde rasyonel ilaç kullanımı”, Çocukluk Çağında Psikofarmakoloji içinde, A. Aysev ve K. Gürkan, ed., (Ankara: Ankara Üniversitesi Basımevi 2009), 29-67.
} 
Beyni Anlamak Sadece Nörobilim ile Mümkün Mü?

ihtiyaç duyuluyor? İnsan gibi düşünen ve hareket eden yapay canlılar insan kontrolünde, savaşta kullanılmak gibi, insanlığın bu teknolojiye sahip olmayan başka bir kesimi için yıkıcı veya öldürücü olabilir mi? Ya da insanların kontrolünden çıkıp dünyada güncel bilimkurgu filmlerinde de işlendiği gibi kaosa neden olabilir mi? Gerçekten de üzerinde düşünmeye değer.

Beyin yüzyılında dengeleyici veya frenleyici bir faktör olarak nöroetik alanına çok iş düşecek. Bu satırların yazarı olarak kanaatim nörobilimin önceliklerini yapay beyin, düşünce kontrolü vb. insanlık aleyhine de kullanılabilecek konulardan çok daha erdemli insan yetiştirmek için eğitim sistemini gözden geçirmek ve insanların halen en önemli sorunları arasında yer alan otizm, şizofreni ve alzheimer gibi ciddi beyin hastalıkları ile ilişkili radikal çözümler üretmek gibi konulara vermesi gerekiyor.

\section{Sonuç}

Bu yazıdan çıkarabileceğimiz en önemli sonuçları şöyle sıralayabilirim. İçinde bulunduğumuz yüzyıl beyin araştırmalarının etkili bir şekilde sürdürüldüğü bir dönem olacaktır. Geldiğimiz noktada beyin işlevlerinin net olarak tanımlanabilmesi sadece nörobilim çerçevesinde ve indirgemeci yaklaşımlarla mümkün görünmemektedir. Beyni anlayabilmek için sosyal bilimlerin bazı önemli disiplinlerinin de işe karıştı̆̆ 1 multidisipliner bir yaklaşıma ihtiyaç olacaktır. Öte yandan beyin sadece nöronlardan ibaret değildir ve nöronlar haricindeki bölümlerin de hesaba katılması gerekmektedir. $\mathrm{Bu}$ durumda nörobilimden ziyade bir "beyin bilim" disiplininden söz etmenin zamanı gelmiştir. Nörobilim ancak beyin bilimin altında bir yan dal veya alt disiplin olabilir. Beyin yüzyılında önemli beyin hastalıklarının tanı ve tedavisine yönelik belirgin gelişmelerin gerçekleşeceğini şimdiden öngörebiliriz. Ancak beyin faaliyetlerini tam olarak anlama, yapay beyin üretme, dışarıdan herhangi bir ilaç veya madde vermeden beyni ve/veya düşünceyi değiştirme gibi konuların, insanı anlamaya dayalı yeni bir hukuk sisteminin ve daha barışçıl, birbirini anlayan insan ve toplumların oluşması gibi hedeflerin ne ölçüde ve nasıl gerçekleşeceğine muhtemelen yine insan beyni karar verecektir. 


\section{İ. Tayfun UZBAY}

\section{KAYNAKC A}

Adam Zeman, “Consciousness. A User's Guide”, (Suffolk: Yale University Press 2002).

Adina Roskies, "Neuroethics for the new millennium", Neuron, 2002, 35, 21-23.

Andrew Koob, Düşüncenin Kökeni, çev. Nilgün Güngör, (İstanbul: Alfa Basım Yayım Dağıtım San. ve Tic. Ltd. Şti., 2011).

Anneliese A Pontius, "Neuroethics vs neurophysiologically and neuropsycholocically uninformed influences in child-rearing and education emerging hunter-gatherers, and artificial intelligence models of the brain", Physiol Rep, 1993,72, 451-458.

Benjamin Libet, Curtis A Gleason, Elwood W Wright ve Dennis K Pearl, "Time of conscious intention to act in relaion to onset of cerebral activity (readiness-potential): The unconscious initiation of a freely voluntary act", Brain, 1983,106, 623-642.

Catherine Malabou, What Should We Do Our Brain? (New York: Fordham University Press, 2008).

Catherine Malabou, Self and Emotional Life, (New York: Columbia University Press, 2013).

Cathy Helgason, "Commentary on the significance for modern neurology of the 17th century B.C. Surgical Papyrus", Can J Neurol Sci, 1987,14, 560-563.

Cemal Bali Akal, Hukuk ya da Kukla Tiyatrosu, (Ankara: Dost Kitabevi 2014). 
Beyni Anlamak Sadece Nörobilim ile Mümkün Mü?

Daniel Lord Smail, On Deep History and the Brain, (Berkeley: University of California Press 2007).

David Eagleman, Incognito. The Secret Lives of the Brain, (New York: Pantheonbooks 2011).

Don Todman, "Henry Dale and the discovery of chemical synaptic transmission", Eur Neurol, 2008, 60, 162-164.

Donald Hebb, The Organization of Behavior, (New York: Wiley \& and Sons 1949).

Elizabeth F Loftus, "Memory distortion and false memory creation", Bull Am Acad Psychiatry Law, 1996, 24, 281-295.

Elizabeth F Loftus, "Eyewitness testimony in the Lockerbie bombing case", Memory, 2013, 21, 584-590.

Francisco López-Muñoz, Fernando Marín ve Cecilio Alamo, "The historical background of the pineal gland: II. From the seat of the soul to a neuroendocrine organ", Rev Neurol, 2010, 50, 117-125.

Frank R. Freemon, "Galen's ideas on neurological function", J Hist Neurosci, 1994, 3, 263-271.

"General Assembly of the World Medical Association. World Medical Association Declaration of Helsinki: Ethical principles for medical research involving human subjects", J Am Coll Dent Summer, 2014, 81, 14-18.

Giacomo Rizzolatti ve Laila Craighero, "The mirror-neuron system", Annu Rev Neurosci, 2004, 27, 169-192.

Giocamo Rizzolatti ve Maddalena Fabbri-Destro, "Mirror neurons: from discovery to autism", Exp Brain Res, 2010, 200, 223-237. 


\section{İ. Tayfun UZBAY}

Gül Eren ve Emrah Özbay, "Karl Marks ve Charles Darwin: Emeğin evrimsel tarihine doğru" (çeviri) Sosyal, Evrimsel ve Kültürel Psikoloji Dergisi, Kuzeydoğu Evrimsel Psikoloji Toplumunun 2. Yillık Toplantı Müzakeresi, 2008, 261-290.

Güven Güzeldere, "Vicdan bazen sılar", PsikeArt (Vicdan), 2013, 25, 6-14.

Henriëtte J Bout, Martje J Fentener van Vlissingen ve Edgar D Karssing, "Evaluating the ethical acceptability of animal research", Lab Anim (NY), 2014, 43, 411-414.

Henry Dale, "Pharmacology and nerve-endings (Walter Ernest Dixon Memorial Lecture): (Section of Therapeutics and Pharmacology)", Proc $R$ Soc Med, 1935, 28, 319-332.

Üsküdar University Journal of Social Sciences Year:1 Issue:1

Iain F Purchase, "Ethical issues for bioscientists in the new millennium", Toxicol Lett, 127, 307-313.

İ. Tayfun Uzbay, "Mezopotamya uygarlığında eczacıllk mesleğine dair bir inceleme", Eczacılık Bülteni, 1981, 23, 57-60.

-----------------, Nöropsikofarmakoloji: Rasyonel İlaç Kullanımı, (İstanbul: İstanbul Medikal Yayıncılık 2007).

,"Çocuk psikiyatrisinde rasyonel ilaç kullanımı", Çocukluk Çağında Psikofarmakoloji içinde, ed., Ayla Aysev, Kağan Gürkan, (Ankara: Ankara Üniversitesi Basımevi 2009), 29-67.

--------'A New Approach to Etiopathogenezis of Depression: Neuroplasticity”, (New York: NOVA Publishers 2011).

, "Alzheimer disease and neuroplasticity: New approaches and new targets in pharmacotherapy", Marmara Pharmaceutical Journal, 2012,16, 65-76. 
Beyni Anlamak Sadece Nörobilim ile Mümkün Mü?

, Madde Bă̆ımlılı̆̆ - Tüm Yönleriyle Bă̆ımlılık ve Bă̆ımlılık Yapan Maddeler, (İstanbul; İstanbul Tıp Kitabevi, 2015).

İzzet Bozkurt, Pazarlama İletişimde Sihirli Dokunuşlar, (İstanbul: Kapital Medya Hizmetleri 2013).

James Olds ve Peter Milner, "Positive reinforcement produced by electrical stimulation of septal area and other regions of rat brain", J Comp Physiol Psychol, 1954, 47, 419-427.

John Henry Gaddum, "Serotonin-LSD interactions", Ann N Y Acad Sci, 1957, 66, 643-648.

Jon Queijo, Büyük Buluşlar, çev. Ekin Duru. (İstanbul: Alfa Yayınları 2011).

Jonathan Pevsner, "Leonardo da Vinci, neuroscientist", Sci Am Mind, 2014, 23 (Winter), 48-55.

Joseph J Schildkraut, "The catecholamine hypothesis of affective disorders. A review of supporting evidence", Am J Psychiatry, 1965, 122, 509-522.

Judy Illes ve Stephanie J. Bird, "Neuroethics: A modern context for ethics in neuroscience", Trends Neurosci, 2006, 29, 511-517.

Lou Marinoff, Prozac'ı Birak Platon'a Bak. Felsefe Terapisi, (İstanbul: Profil Yayıncilik 1999).

Luigi Cattaneo ve Giocamo Rizzolatti, "The mirror neuron system", Arch Neurol, 2009, 66, 557-560.

Maria M Klavdieva, "The history of neuropeptides II", Front Neuroendocrinol, 1996, 17, 126-153.

Martha J Farah ve Paul Root Wolpe, "Neuroethics toward broader discussion", Hastings Cent Rep, 2004, 34, 35-45. 


\section{İ. Tayfun UZBAY}

Metin Özbek, "Trepanasyon. Eski çağlarda beyin ameliyatı”, Aktüel Arkeoloji, 2014, 42 (Kasım - Aralık): 98-105.

"Milestones in Neuroscience Research", Erişim 1 Ağustos 2015, https://faculty.washington.edu/chudler/hist.html

Nicola J Allen, “Astrocyte regulation of synaptic behavior", Annu Rev Cell Dev Biol, 2014, 30, 439-463.

Robert E Burke, "Sir Charles Sherrington's The integrative action of the nervous system: a centenary appreciation", Brain, 2007, 130, 887-894.

Santiago Ramón y Cajal, "Histologie du systeme nerveux", (Paris: A. Maloine 1911).

Üsküdar University Journal of Social Sciences Year:1 Issue:1

, "Degeneration and regeneration of the nervous sytem", (Oxford: Oxford University Press 1928).

Seong-Gi Kim ve Seiji Ogawa, "Insights into new techniques for high resolution functional MRI", Curr Opin Neurobiol, 12, 607-615.

Shitij Kapur ve Yves Lecrubier, Dopamine in the Pathophysiology and Treatment of Schizophrenia, (Abington - Oxon: Taylor \& Francis 2014).

Steven H Zeisel, "A brief history of choline", Ann Nutr Metab, 2012, 61, 254-258.

Tayfun Uzbay, "Nöropazarlama ve beyin ödül sistemi", Pi Pazarlama ve Illetişim Kültürü Dergisi - Nöropazarlama: Tüketici nasıl karar alır?, 2014, 13(47) Kış, 46-50.

,"Bilimsel araştırma etiği”, Sağlık Bilimlerinde Süreli Yayıncılık-2006 içinde, ed. Orhan Yılmaz, (Ankara: TÜBİTAK Matbaası 2006), 19-26. 
Beyni Anlamak Sadece Nörobilim ile Mümkün Mü?

Wouter W De Herder, "Heroes in endocrinology: Nobel Prizes", Endocr Connect, 2014, 3, R94-R104. 